\title{
Accessibility and utility of library resources in research methodology course: A case of non-science students at the University of Malaya
}

\author{
Muhammad Danial Azman'1, Mashitah Hamidi² and Siew Kian Ong ${ }^{3}$ \\ ${ }^{1}$ Department of International and Strategic Studies, Faculty of Arts and Social Sciences, \\ University of Malaya, 50603, Kuala Lumpur, MALAYSIA \\ ${ }^{2}$ Department of Social Administration and Justice, Faculty of Arts and Social Sciences, \\ University of Malaya, 50603, Kuala Lumpur, MALAYSIA \\ ${ }^{3}$ Department of Chinese Studies, Faculty of Arts and Social Sciences, \\ University of Malaya, 50603, Kuala Lumpur, MALAYSIA \\ e-mail: danial@um.edu.my (corresponding author); mashitah_hamidi@um.edu.my; \\ siewkian@um.edu.my
}

\begin{abstract}
This paper investigates the accessibility and utility of library resources when studying research methodology among the non-science students at the University of Malaya Kuala Lumpur. It addresses the primary concerns of accessibility and utility among students when engaging library resources and undertaking the core subject "Research Methodology" both at the faculty level, as well as at three departments under the Faculty of Arts and Social Sciences. In doing so, survey questionnaires were distributed among students doing research methodology across three distinct yet interrelated subfields of the Arts and Social Sciences, namely Anthropology and Sociology, Chinese Studies, and International and Strategic Studies. This descriptive study employs both quantitative and qualitative data gathering techniques through: (a) survey captured through an email invitation to a specific target of undergraduate and postgraduate students who have completed their research methodology course; (b) a focus group discussion (FGD) conducted to discuss students' responses toward initial findings from the surveys. The findings indicate that despite the pivotal role played by the library in facilitating the learning of research method, there is greater need to recognise the specific needs of library resources in research methodology in Arts, Humanities and Social Sciences. This should be able to help the acquisition division of respective university libraries in their future planning, particularly given the variety and diversity of research traditions in the non-science discipline.
\end{abstract}

Keywords: Research methods courses; Library resources; Library usage; Academic libraries; Arts and Social Sciences

\section{INTRODUCTION}

Since the growing popularity of the field of library sciences in strengthening the existing pedagogy activities of the university, previous literature in Library and Information Sciences (LIS) has recognised the pivotal roles of the library in accommodating old and new resources, especially in integrating interactive methods in teaching and learning activity ( $O^{\prime}$ Connor 2015; 
British Library 2016). As such, the growing number of online educational resources has provided an instructive opportunity for the university to recognise the essential roles of the library in providing appropriate resources in learning research methodology (Gerring 2012; Dunn and Woods 2016) and this acknowledges the crucial roles played by the university's library in facilitating and enhancing the existing pedagogy activities in research methodology. Meanwhile, Boxall, Brady and Collier (2008), Sandra and Heath (2012) and Leavy (2014) conclude that there is a strong relationship between the library's information literacy courses, accessibility and utility of the library resources in searching for knowledge when students are learning research methodology in social sciences.

In arts and social sciences, the broad use of the ethnographical method in anthropology, sociology and feminist research is not guided by the same rules of quantitative research that rely heavily on instrumentalising the statistical analysis software (such as the Statistical Package and Service Solutions, SPSS) as for the cases of most research in applied social sciences, such as in geography, economics, management and development studies (Tickner 2005). Meanwhile, the primary reliance of archival and document-based research in the content analysis used in political history, international relations and defence analysis differs from the study of public administrations with a heavy dependence on the statistical or numerical analysis in their data triangulations, and during the specific learning of its research methodology classes (Lamont 2013). In addition, the broad use of discourse analysis and hermeneutic methods in literary criticisms in the discipline of arts, linguistics, humanities, and classical poems and scriptures cannot be compiled under a pretext of research methodology training of other subfields belonging to the arts and social sciences (Cohen 2009). According to Gerring (2012) and Newman (2013), it is more important to recognise that different methodological preferences are deeply embedded in the ontological and epistemological traditions of different disciplines, and such convergence intersects with the use of particular library resources, rather than adopting a strategy of one-fit-for-all of the standard modules, textbooks, reading lists, materials, electronic resources and software under the vague term of 'research methodology in social sciences' (Forrestal 2015).

This study explores the issue of accessibility and utility of library resources in teaching and learning a course on research methodology in three major subfields of arts and social sciences, namely anthropology and sociology, Chinese studies and politics and international relations. Given the new curriculum review and syllabus since 2015, the students at the Faculty of Arts and Social Sciences, University of Malaya Kuala Lumpur, have to undertake several core courses of Research Methodology either at the school or departmental level. With that, all learning and teaching activities in research method engage various types of library resources. In return, when students are actively exploring multiple library resources in learning research methodology, there is a need to investigate the accessibility and utility of the library resources among students.

Arguably, the library acquires resources in meeting the needs and demands of its users. Maitaouthong, Tuamsuk, and Tachamanee (2012) highlight the fundamental task of the library in spearheading knowledge dissemination, particular on the library's ability to ensure accessibility and utility of various resources. To date, there has been no systematic study within the LIS literature to identify if there is a need for the specific teaching and learning resources for the students in research methodology, and in the specific field of Arts and Social Sciences. Given the backgrounds of the authors of this paper in teaching research methodology course in the three different departments, we examine if there is a reasonable need to accommodate and support different materials needed by the postgraduate and undergraduate students. By doing so, we are exploring accessibility and frequency of utilising 
the library resources among students learning research methodology in the Arts and Social Sciences.

\section{LITERATURE REVIEW}

\section{Library Resources for Research Methodology for the Non-Sciences}

The main function of the library in learning resources is to enable students and teachers to prepare for learning, teaching and research typically in higher education institutions. Teaching and learning materials are the library resources required by students for their academic and research activities. Library resources can be referred as anything that can provide intellectual stimulation to the learners and traditionally includes books, periodicals, newspapers, pamphlets and ephemera, audio materials, film materials, and computers (Popoola and Haliso 2009; Adeoye and Popoola 2011). Fayose (2000) identifies a library resource as those materials which enable libraries to carry out their function effectively as academic libraries have long been recognised as the heart of its institutions. Hislop (2013) recognises the efforts of the university libraries in communicating with various academic departments before the beginning of the teaching semester, particularly when the library is requesting course information or suggested essential reading texts from the respective course lecturers. Notably, a library designs its collections and services to meet the institutional programs of the institution. Using the library for material or research purposes has a direct connection to students' educational outcomes (Nagata, Todan and Kytömäki 2007).

The ability of the university to produce learning and research outputs in various subfields in arts and social sciences has been connected to the quality of the resources provided by the library (Bryman 2012). At the minimal level, the library recognises the diversity of fields in arts and social sciences and that providing necessary but different resources in learning research methodology is crucial. Despite priority given to teaching and learning resources, subjectspecific resources have been neglected, including those concerning research methodology. Brown and Swan (2007) found that even in the most research-intensive institutions, priority is still given to resourcing teaching needs rather than research needs. This limits the input of research materials that should be provided for teaching and learning research methodology, which is regarded as one of the most important subjects in arts and social sciences.

While teaching and learning activity of research methodology subject across various disciplines in the non-sciences are guided by a relatively similar, various pedagogical and epistemological traditions in those fields have emerged. Corti (2012) highlights the dangers of adopting a one-fit-for-all strategy when assuming that all subfields in arts and social sciences utilise similar resources when conducting research methodology course. For example, Jupp (2006), Klotz and Prakash (2008) and Yang (2013) highlight the different resource needs in learning research methodology between the ethnographic method adopted in feminist research methods, and the widespread usage of the SPSS software in applied social sciences, such as in geography, economics and development studies. Given such diversity and competing tensions over limited resources, Hislop (2013) advises the central library of many developing universities to close the gap through conducting surveys among students who have undertaken the research methodology course to capture the accessibility and frequency of library resources utilised by the students when learning the subject.

\section{Accessibility to Specific Research Methodology Resources in the Non-Sciences}

Accessibility of teaching and learning resources is an important recurring theme in the literature. Although resources may be available in the library and even identified 
bibliographically as relevant to one's subject of interest, the user may not be able to borrow the materials. Adeoye and Popoola (2011) argue that the more accessible information sources, the more likely they are to be used. They note that the availability of learning resources does not necessarily imply its accessibility because the source may be available, but access to it prevented for one reason or the other. Most users including researchers understand that despite having interest in certain resources, discovering and access it could be difficult (Brown and Swan 2007).

There are two indicators to understand the accessibility of resources and behaviours among users to access library resources. Firstly, Ugah (2008) argues that while learning resources are available, they are not easily accessible to the users due to reasons such as poor indexing and cataloguing, an inefficient loan and circulation system, poor shelving, lack of adequate guides to library arrangements, as well as administrative and physical barriers. Secondly, readers tend to use information sources that require the least effort to access. These observations have been validated by empirical studies such as those by Rosenberg (1967), Allen (1968), Zha, Li, and Yan (2012), Dukic and Striskovic (2015), Maximilliano et al. (2016) and Eiriemiokhale and Ibeun (2017). These findings supported Griffiths and Brophy's (2005) who argue that 45 percent of students use Google as their first port of call when locating information, while the university library catalogue was used by 10 percent of the sample.

Limited knowledge and awareness of materials offered by the library among users are one of the challenges in understanding accessibility to learning resources. Most of the users, particularly students, view the library as the place to borrow books and the place to perform revisions without realising the richness and numerous materials provided by their library (Oyewusi and Oyeboade 2009). This contributes to the problem of accessing subject-specific materials. One solution to accessibility suggested by Brown and Swan (2007) is that users or "researchers in all disciplines welcome the delivery - through the library and other sources of digital content direct to the desktop; they are eager for more to be made available; and both researchers and librarians see this as the key driver requiring libraries to change the way they deliver services" (p.18).

\section{Utility to Specific Needs of Research Methodology Resources in the Non-Sciences}

Unlike traditional pedagogical activity of the ordinary subjects, materials and resources for learning research methodology are often directly connected to a fundamental gateway to new knowledge production (Bryman, Becker and Sempik 2008). Rather than being simply transmitted from a teaching activity, learning and identifying a specific research tradition of the specific discipline is guided by the epistemological divisions that have existed and conditioned the research output of the discipline (Bryman 2012). Apart from the binary distinction of qualitative and quantitative methods, unique variations appear to be critical, either on the ontological differences between positivist and post-positivist or at the level of the research design's orientations between empirical and interpretive exercises (Gerring 2012).

The relative subjectivity of various research traditions in social sciences urges both teachers and students to be more flexible and diverse in dealing with uncontrolled research environments in the social sciences beyond lab experiments (Newman 2013). Consequently, such ontological and epistemological richness condition the diverse material needs of methodological learning activities and preferences of utilising diverse resources or tools, rather than simply assuming that it is categorically confined in a single category of nonsciences or non-quantitative activities (Finnemore and Sikkink 2001). By referring to Cox (1981), we conclude these methodological debates and differences as simply a case of theory 
or research about someone or something rather than a universal approach to everything. This affects the way library resources are acquired when learning research methodology (Werhane and Moriarty 2009). While these research activities are diverse and commonly guided by similar models of teaching and learning research methodology, the most basic lessons when introducing types of research skills, methods, designs and frameworks are bound by the particularity and utility of a resource that may not be available in other subfields of social sciences.

Baert (2005) remarks that the frequency of utilising particular resources among students in learning research methodology is dependent upon the specific nature of the discipline and its philosophical assumptions about the object of analysis and its social reality. Secondly, it depends upon a preferred method that cannot be simply classified under the broad term of 'research methodology in social sciences'. Finally, even if the specific field within the discipline of arts and social sciences has a strong preference in utilising a particular library resource when facilitating learning activity in research methodology, it must consider the students' library literacy in training and utilise a particular resource in ensuring their competency. As such Bryman (2012) and Marshall (2016) largely agreed with Baert's (2005) advice on the issue of utilising library resources in learning research methodology in arts and social sciences that it is best to adopt the methodological position formulated by King, Keohane and Verba (1996). In this respect, King, Keohane and Verba (1996) recognise the importance of equipping and exposing students of arts and social sciences in their learning of research methodology with the ability to utilise primary methods adopted by the disciplines and competency in exploiting library resources.

\section{OBJECTIVE AND METHOD}

The purpose of this study is to examine the use of library resources among non-science students in learning research methodology. Specific objectives are:

(a) To identify the role of the university library in supporting research methodology courses in Arts and Social Sciences.

(b) To examine accessibility awareness of resources for research methodology provided by the university library among postgraduate and undergraduate students.

(c) To discuss the way students utilise library materials for research methodology at postgraduate and undergraduate levels.

The following research questions are addressed:

(a) What are the available resources for learning research methodology in arts and social sciences, provided by a university library?

(b) To what extent are postgraduate and undergraduate students aware and able to access research methodology resources in a university library?

(c) How do postgraduate and undergraduate students utilise research methodology resources and, why do they favour a particular resource?

This research utilises case study as the research design, using questionnaire and focus group discussion (FGD) as the data gathering techniques. It focuses on a single case of students from three different departments at the Faculty of Arts and Social Sciences, University of Malaya Kuala Lumpur. The selection of a single case study research design is used "to demonstrate a casual argument about how general social forces shape and produce results in particular settings" (Walton 1992, p.131). Therefore, this approach is deemed relevant and applicable to the study, where students in arts and social sciences were observed during the research 
methodology classes when engaging library resources. Using a case study research design enables the researchers to capture questionnaire data, and to substantiate their initial responses through FGDs. Additionally, the case study was not selected as a design for the study with the aim of making generalisations, but rather to understand patterns of accessibility and utility when students of arts and social sciences are engaging with library resources in their research methodology classes. Yin (1984) confirms this by stating that one possible rationale of a single case study is that the case represents a critical opportunity in investigating a pattern of responses among the subjects of the study. Yin (1984) further explains that focusing on a single case study entails determining if the propositions of the research objectives and questions are correct, or if there are alternative explanations that are more relevant to explain a social phenomenon. The main reason of focusing our research on the students of the Faculty of Arts and Social Sciences is because we are constantly interacting with them during our instructional activities in research methodology. In return, it increases our familiarity with the respondents and their level of information literacy, especially when dealing with a technical subject of research methodology.

In conducting the research, the case study approach is divided into two main parts. The first involved the distribution of questionnaires among students of arts and social sciences, during their research methodology classes. A student questionnaire was developed, and each respondent was asked to provide (a) their demographic information, (b) their rating on the accessibility values of learning resources, as provided by the library, and (c) their rating on the utility values of learning resources, as provided by the library. Every value was to be rated based on two types of scale. The first is the dichotomous style decoded as $1=y e s$ and $2=$ no in terms of the student's familiarity with the general resources provided by the library, its customer services and frequency of using library resources. The second is Likert scale, decoded as $1=$ =xtremely useful, $2=$ very useful, $3=$ somewhat useful, $4=$ slightly useful, $5=$ not useful at all, in terms of accessibility and utility of all types learning resources in research methodology as provided by the library. Upon completing the questionnaires, we substantiated the survey database based on the findings from the FGD.

The second part involved the use of FGD which was carried out to observe the interaction between the lecturers, students and library resources in research methodology classes. We further select 16 students (from those who responded to our questionnaire) as our unit of analysis, who were divided into two groups comprising undergraduates and postgraduates. Through group discussions, we asked additional questions on reasons for preferring particular library sources over others. Our aim is to triangulate the validity and reliability of answers or opinions provided by the students when facing a set of questionnaires. FGD in the most controlled form is a group interview or collective discussion with those students who have previously answered the survey. The interviews or discussions were guided by the three research objectives. Unlike structured questionnaires, FGDs allow students to participate in the freer flowing discussion, or to 'take over' or 'own' the interview space, while remaining organised and guided by our research objectives and the answers in the initial questionnaire. Through the FGD, we investigate reasons and justifications and seek further clarification of answers in the survey in order to establish patterns of understanding, which illuminate their attitude, preference and behaviour in using library resources for research methodology activity. Nonetheless, the careful selection of participants during the FGD is the key for the researchers to readily distinguish the objective facts (as appeared in the questionnaire) from subjective opinions and suggestions, allowing us to discover more solid findings and patterns of accessibility and utility of library resources. 
This research employed a targeted sampling technique where e-mail invitations to the survey link were distributed to respondents' e-mail addresses. The e-mail addresses were obtained from the Faculty's registrar office. The sample size was determined based on Krejcie and Morgan's (1970) on population and sample table. With a population of 1310 students (as informed by the registrar at the point of data collection), the students consist of 790 undergraduates and 520 postgraduates. Given that population, the sample size was determined as 120 (from three major departments), consisting of 40 students from the Department of Anthropology and Sociology, Department of Chinese Studies, and Departments of International and Strategic Studies respectively (confidence Level $=95 \%$, margin error $=3.5 \%$ ). In each department, we divided the ratio of the questionnaire between 30 undergraduate and 10 postgraduate students who completed their coursework in research methodology. All 120 respondents were approached through a specific e-mail invitation which contained a hypertext link enabling the participants to link the survey database hosted in Google Drive, after completion of the course lectures. After two rounds of distributions, replies were received from 110 respondents out of which about 90 percent were completed and used for analysis. The response rate is exceptionally good for an online survey. This is due to the specific instructions given by the lecturers to the students when completing the surveys. This was done by constantly reminding the students to respond to the survey during the 14 weeks of lectures. Table 1 indicates the survey demographics and response.

Table 1: Survey Demographics and Response

\begin{tabular}{lr}
\hline \hline Total population & 1310 \\
\hline \hline Undergraduates & 790 \\
\hline \hline Postgraduates & 520 \\
\hline \hline Total sample & 120 \\
\hline \hline Undergraduates & 90 \\
\hline \hline Postgraduates & 30 \\
\hline \hline Clicked on survey link & 110 \\
\hline \hline Completed survey & 110 \\
\hline \hline Non-completion & 10 \\
\hline \hline Response rate & $91.2 \%$ \\
\hline \hline
\end{tabular}

\section{RESULTS}

\section{Survey Findings}

A total of 110 (91.2\%) postgraduate and undergraduate students responded on their knowledge of the availability of library resources. Most of the respondents are undergraduate students who rely on library resources in facilitating their learning of research method. The undergraduates $(90,68.2 \%)$ have completed the Information Literacy course, which is a core course, offered by the university library. The postgraduates $(30,31.8 \%)$ have gone through the information skills sessions, which is also provided by the University of Malaya (UM) Library. Most of the respondents $(110,95 \%)$ were aware of the various facilities or resources provided by the library. Table 2 presents findings on the respondents' familiarity with various types of information sources.

Findings indicate that most respondents are familiar with the common resources provided by the library, such as printed books, e-books, printed journals, e-journals and thesis / dissertations (each received over $85 \%$ of awareness score). These figures show that both undergraduates and postgraduates are familiar with most of the services provided by the 
library, and this study suggests that the library has provided the extensive resources to support general learning and research. However, the services of the UM library are not limited to the book collections and databases. In addition to common resources, the library also provides more specialised services for research needs, through inter-library loans, Malaysian catalogues, microfilms and microfiches, and references desk, which are regarded to be very useful in supporting research methodology classes. Unfortunately, a much lesser percentage (70\% and below) of students are familiar with these four specific resources. When students claimed limited familiarity of these specific resources, they opted not to learn how to access and utilise these resources.

Table 2: Student's Familiarity with the Library's Resources and Services

\begin{tabular}{clcc}
\hline \hline & Types of Library Resources & $\begin{array}{c}\text { No. of } \\
\text { respondents }\end{array}$ & $\begin{array}{c}\text { Percent } \\
(\%)\end{array}$ \\
\hline 1 & Printed books & 105 & 95.5 \\
\hline 2 & E-books & 94 & 85.4 \\
\hline 3 & Printed journals & 89 & 80.9 \\
\hline 4 & E-journals & 98 & 89.0 \\
\hline 5 & Databases & 107 & 97.2 \\
\hline 6 & UM thesis and dissertation collections & 103 & 93.6 \\
\hline 7 & Inter-library loans & 36 & 32.7 \\
\hline 8 & Malaysiana collections & 77 & 70.0 \\
\hline 9 & Microfilms and microfiches & 67 & 60.9 \\
\hline 10 & References collections and references desk & 34 & 30.9 \\
\hline 11 & E-mails and library's social media (Facebook, Twitter, Instagram) & 82 & 74.5 \\
\hline 12 & Main library webpage & 109 & 99.0 \\
\hline 13 & Pendeta Discovery & 109 & 99.0 \\
\hline 14 & Interaktif Portal & 98 & 89.0 \\
\hline \hline
\end{tabular}

Source: Survey data captured and hosted in the Google Drive.

For example, the usefulness of inter-library loans (though limited) is in overcoming the unavailability of research method books in learning a specific methodology during data collection or fieldwork. While we have found a low level of familiarity (36, 32.7\%) among respondents in knowing the existence of inter-library loan services, most students (85, 72.2\%) preferred not to use these alternative resources, or simply do not know that they exist. Similarly, on the availability of reference desk, Malaysiana collections, and microfilm and microfiches, most $(89,80.9 \%)$ respondents decided not to utilise these specific resources. As for the case of Malaysiana collections, while 70 percent (77) of respondents are aware of the usefulness of such resources when researching Malaysian studies, few $(15,20 \%)$ decided to use such resources. Among students of arts and social sciences, this highlights a declining trend when researching a topic that only focused on Malaysian studies.

Nonetheless, most respondents $(109,99.0 \%)$ are familiar with the availability of Main Library webpage (https://umlib.um.edu.my/), when browsing for resources in research methodology. For specialised websites such Pendeta Discovery (a public access catalogue and resource discovery tool) and Interaktif Portal (the library portal to e-resource and e-services), and by average, only a few respondents $(38,35.4 \%$ ) can be regarded as frequent users (few times a week) of the Interaktif Portal when browsing for databases, e-books and e-journals. Meanwhile, the utility of Pendeta Discovery (for browsing books and other collections) for research methodology is higher among respondents who preferred hard copies of research method textbooks as opposed to electronic textbooks. However, the frequency of users (47, 
42.7\%) (either every day or few times a week) of Pendeta Discovery remained unsatisfactory during the research methodology classes.

We also investigate the students' accessibility to the special libraries located within the the UM Library (such as libraries for Chinese, Indian and East Asian Studies) and those special subject libraries in other academic entities (including, Za'ba Memorial Library, Islamic Studies Library, Economics Library, Asia-Europe Institute Library, Malay Studies Library, Law Library, Languages \& Linguistics Library and Medical Library). The respondents showed the level of awareness of the specialised libraries within or outside the Faculty of Arts and Social Sciences that provide specific resources for researching and writing in area studies, humanities and social sciences. The survey showed that 70 students $(63.6 \%)$ were aware of the availability of such resources and 40 students (36.4\%) were not aware with those resources provided. Nonetheless, we believe that there is a limited library awareness among the respondents (even if they have been informed by the librarians during the orientation week), especially in accessing and utilising these special libraries to enrich their resources for constructing literature reviews.

Apart from investigating students' familiarity with the general library resources on research methodology, we also investigated their familiarity with the SAGE Research Methods database ${ }^{1}$ (which is available through library's Interactive Portal available at http://www.diglib.um.edu.my/interaktif/). To date, this is the only database subscribed by the UM Library dedicated to providing technical knowledge in research methodology in the social sciences. We attempted to gauge its accessibility and utility among students. The availability of these online resources is one of the plausible ways for the library management to overcome the existing limitations in printed materials for research methodology, especially in the arts, social sciences and humanities. Through the SAGE Research Methods database, students can learn how to design their research, formulate research questions, arrange their literature review and gain additional and interactive information, especially on various relevant video clips from experts in using various methods during data collection or data analysis. The database focuses on broad-based spectrums of social sciences and humanities, ranging from major approaches in qualitative, quantitative and mixed methods in various subfields including linguistics, social studies, criminology, legal studies, politics, psychology, economics, history, development and feminist studies, sociology, anthropology, and culture.

Statistical reports obtained from the UM Library indicate a growing number of users of SAGE database for the UM campus. From 1,798 users during the database's first availability in 2013, the number of users has increased to 2,866 in 2014. However, the overall users had decreased to 1,322 in 2015, when a full subscription of this database was reduced to partial subscriptions (limited contents for UM users). By 2016, while the status of the database was reduced to a trial version, the number of users increased to 2,598. Nonetheless, our e-mail correspondence with the library has confirmed that the overall data that they captured does not identify specific user type (either academic staffs or students), and even if we assume these users are mostly students, they do not identify a specific sample or representative of the student from the Faculty of Arts and Social Sciences.

Our survey has shown a contrasting result. Regardless of study levels (either at the postgraduate or undergraduate level), only 14.5 percent (16) of the sampled students knew about this database, and 59.1 percent (65) have no previous information about the existence

\footnotetext{
${ }^{1}$ Provides full access to SAGE books, journal articles, reference works, case studies, sample datasets and videos about designing and conducting a research project, specific research methods, performing a literature review and writing about research results.
} 
of this database. Among the 40.9 percent (45) respondents who have heard about the database (through library news and e-mail updates), only three (2.7\%) are postgraduates. In addition, while only 40.9 percent (45) of respondents are aware about the database, only 31.8 percent (35) access and utilise the database.

Findings depicted in Table 3 show that 56.4 percent (62) of respondents were unaware the database existed, and even if a high 85.5 percent (93) of the respondents knew about the database, 29.1 percent (32) reported have opted not to use it since they were not familiar with its functions. This shows that the actual accessibility and utility of SAGE Research Methods database are at an average level. These findings indicate the need for more targeted awareness campaigns among students on the use of this database, to ensure that the database is not underutilized. Given the high awareness but low utilization of the SAGE Research Methods database among students, the library should provide specific training and workshops to teach the students on how such database can be a useful resource in research methodology. Similar efforts have been concerted by the UM Library, especially when providing a weekly workshop on using Endnote software to help researchers gather, manage and cite references to scholarly literature and resources. In our survey, 68.2 percent (75) of the students agreed that the library should provide a workshop or one to one consultation on how to use a specialised database. Concerning the question as to whether the library should subscribe to more databases for learning research methods, the result is encouraging -82.7 percent (91) agree that the library should subscribe to more research methodology databases, reflecting that those who have used the database would like have more online resources that comprehensively covers the range of research methods and teaching datasets for statistical and analytical techniques used in the non-sciences. Table 3 presents the overall findings on the awareness and utility of Research Method database.

Table 3: On Students' Awareness and Utility of Research Method Database

\begin{tabular}{lccc}
\hline \hline Awareness & $\begin{array}{c}\text { Yes I know, have } \\
\text { used it }\end{array}$ & $\begin{array}{c}\text { Yes I know, } \\
\text { haven't used it }\end{array}$ & I don't know \\
\hline \hline $\begin{array}{l}\text { Student's awareness of the } \\
\text { subscriptions of the SAGE Research }\end{array}$ & $\begin{array}{c}14.5 \% \\
(16)\end{array}$ & $\begin{array}{c}29.1 \% \\
(32)\end{array}$ & $\begin{array}{c}56.4 \% \\
(62)\end{array}$ \\
Methods database & & No & No comment \\
\hline \hline Utility & $68.2 \%$ & $3.6 \%$ & $28.2 \%$ \\
\hline \hline Student's opinion on a specific & $(75)$ & $(4)$ & $(31)$ \\
workshop for a specialised database & $82.7 \%$ & $14.5 \%$ & $2.8 \%$ \\
\hline \hline Student's opinion on more & $(91)$ & $(16)$ & $(3)$ \\
$\begin{array}{l}\text { subscriptions for Research Methods } \\
\text { database }\end{array}$ & & & \\
\hline \hline
\end{tabular}

Source: Survey data captured and hosted in the Google Drive.

\section{Focus Group Discussion (FGD) Findings}

The qualitative data from the questionnaire were incorporated with further qualitative data collected from two FGDs with eight participants in each group, representing the three departments sampled. The selected excerpts from the discussions with both undergraduate's (UG1-UG8) and postgraduate's (PG1-PG8) focus group participants are categorized under three central themes:

(a) Library's provision of Research Method resources

(b) Students' awareness of Research Method resources

(c) Students' perceived utility of Research Method resources 


\section{(a) Library's Provision of Research Method Resources}

In general, students recognise the overall functions of the library in facilitating teaching and learning activities, especially on making available various research methods resources to provide students with a richer research experience. Furthermore, students overwhelmingly support the massive infrastructural renovations and acquisitions improvements for the library to cater for the growing needs of various sub-disciplines in social sciences. However, while students acknowledge the critical connections between research methodology classes and library resources, most found that there is a real gap between pedagogical activity in research methodology, and information on resources provided by the library. The following excerpt confirmed this issue:

UG4: There might be a connection between research methodology and library resources, but we don't see the alignment during our normal lecture and tutorial activity.

A similar problem were echoed by another undergraduate respondent. However, in this student's case, she made an effort to listen to her lecturer's advice and seek further helps from the librarian:

UG8: It is hard to start a research project if we just simply go to the library since we feel a bit unsure how actual learning and practice of research methodology could be supported by the library search itself. But my lecturer did ask me to seek helps from the library on how to access electronic journals or books.

In addition, postgraduate respondents demonstrate their interests to find out more about the means of communications between the lecturers and librarians when suggesting relevant resources for the teaching of research methodology:

PG6: Of course, the Library is very important and look more appealing than my Faculty's facility. But both lecturer and librarian need to follow up with one another frequently, especially when there are new resources for research so they may support each other's activity.

Nevertheless, the students, regardless of their study level, concluded their thoughts that firstly, the library is truly important in teaching and learning of research methodology but there must a clear alignment between librarians and lecturers. Secondly, they cannot understand why lecturers do not engage with the librarians to teach research methodology. Finally, they want more active communication between both stakeholders in order to solve this issue.

\section{(b) Students' Awareness of Research Methods Resources}

In discussing their awareness on the accessibility of library resources, arguably, students realise that the importance of knowledge of various library resources will affect the way they access a preferred resource in research methods:

UG2: I think most of us are only familiar with basic functions of the library. Apart from finding books on the shelves and using electronic resources, our familiarity with the carrel desk and group learning space would be the most common way for accessing the library.

Further discussions with selected undergraduate and postgraduate students have revealed six categories of the library users when learning research methodology. They are:

i) Students who are customarily aware and know how to access library resources. They are most likely to benefit from the availability of resources provided by the library. 
ii) Students who are generally aware of the overall library resources, but find it difficult to identify a specific relevant resource in their subject matter. Only when seeking support from the librarians, they manage to see a connection between library resources and their research methods classes, and in return, they generally take more interest in the latest updates, especially from the library social media sites:

PG5: My research project requires me to consider mostly the resources provided by the Main Library, including the specialised libraries. I spent most of my first research year in getting familiar with these resources so they can be used to help me to finish my thesis writing and journal publication. Given my familiarity with conventional and electronic resources of the library, even though my research methodology lecturer has never introduced them during the classes, I think we have to make self-effort in exploiting all of these resources. This is where we need the librarian and they are equal to the teacher, in my opinion.

iii) Students who are generally aware of the library resources available but partially disagree that these resources help facilitate their research activities. Rather than exploring the resources provided by the library, they prefer to rely on the first-hand knowledge of their lecturer or supervisor.

iv) Students who are generally aware but show limited interest to learn or consider accessing different library resources due to it being time-consuming, irrelevant to their subject matter and having personal preferences over a particular resource:

PG8: My familiarity in accessing library resources are mostly affected by the limited printed editions of major referred works. And when facing with no or limited electronic subscriptions by the university library, the inter-library loan services can be costly. I just hope there would be more reviews on these policies.

v) Students who generally understand the availability of research methodology resources, but found difficulty in accessing them. This is mostly due to technical defaults, including the availability of optimum internet speeds, time-consuming activity, lack of further information on the specific technical knowledge of a particular online database, limited subscriptions, and a limited quantity of printed materials of certain major references, which all determine the overall pattern of student's accessibility. An Undergraduate expressed his view:

UG7: I attended once, the Endnote X workshop organised by the Main Library and I just realised, that there are so many resources that we can all use in our research methodology classes. But some of these resources like the electronic journals can be quite complicated since we forgot all lessons that we had learned during our information literacy classes.

vi) Students who are not aware of the availability of library resources, nor found any connection between the library and learning research methodology. As a result, they show no interest in considering any new research methodology resource in learning research methodology.

\section{(c) Students' Perceived Utility of Research Method Resources}

Regardless of the resources provided by the library, there is a lack of consensus among students in terms of which resources they preferred most when learning research methodology, or when writing their thesis, or shaping their journal article. The deliberations with the FGD participants have identified three conditions that may affect student's perceived utility of research methods resources: 
i) Level of study at the undergraduate or postgraduate levels: In general, there were no clear distinctions among students in arts and social sciences. Limited awareness impacted the patterns of utility for both levels. However, postgraduates tried to improve their awareness, and it is likely to improve their perceived utility of the resources:

PG4: Although our actual research methodology course is rather introductory, we navigate our utility patterns first by browsing textbooks for beginners, and then learning to advance our knowledge on particular method by utilising electronic database, such as the SAGE Research Method [as provided by the Main Library].

ii) Types of resources: Some students preferred more printed books, while others preferred to utilise online resources. The limited subscriptions by the library have shaped their preference for open access. This includes Google, ResearchGate and illegal resource-sharing sites as Sci-Hub, especially when inter-library loans are found to be limited to mostly postgraduate students, or paywalled subscription is too expensive for the students:

PG8: Google Search is the friendliest way to learn about complex research task. I don't hesitate to seek help from the librarian, and my lecturer advises me to do so.

iii) Subject matter: The usage pattern of library resources is determined by students' opinion, preference and attitude in their respective disciplines. For instance, students in Chinese studies preferred specific classical collections on literature, poems and arts from the online database such as JSTOR (Journal Storage) and CNKI (China National Knowledge Infrastructure). While students of politics and international relations preferred wider circulations of reputable commercial publishers (either in the form of printed or e-books). Finally, anthropology and sociology students wish for more improvements on the quantity of major and latest textbooks and more electronic subscriptions, especially specific and the latest research method textbooks for ethnography, cultural studies and sociology, and this specific need should not bound by general textbooks of research methods from the field of education, business and psychology. The following excerpts from students of three different research disciplines confirmed this condition:

PG5: It all depends on the nature of the discipline. For us who are researching on Chinese Studies, we rely a lot on JSTOR and CNKI. They give us the most readily access on distance classical collections from those universities in Chinese-speaking countries. PG6: Given my research focus is on comparative African and Asian Politics and Security Studies, my utility preference is determined by wider availability of either printed or online books or journals by Oxford Press, Cambridge Press, Routledge, SAGE and Palgrave Macmillan. I think, the librarian is helpful in guiding the way to find relevant resources for my research.

PG7: As a research student in Anthropology, my preferred utilisation of library resources is mainly determined by the availability of major and latest textbooks in ethnography, cultural studies and subalterns. But I recognise the university's limited financial endowment to support the library's acquisition of new resources. Of course, the supervisor is the first-hand information, even in finding relevant search terms in the database.

Nevertheless, irrespective of the level of their study, resource type and subject matter, the rest of the participants mostly agreed on the following additional conditions:

i) While there are different knowledge needs and understandings on research methodology among the undergraduates and postgraduates, lack of awareness in 
term of the existing resources have provided a similar general dilemma when utilising research method resources. Both group of students agreed on the important role of the help desk services (in the Main Library) when seeking technical advices on library resources.

ii) The undergraduates found it most challenging in determining a clear connection between library resources and research methodology classes. They simply view the library in the conventional contexts of normal book loans and library space for doing revisions, completing assignments and browsing the Internet. Rather than seeking help from the librarians, they rely heavily on the first-hand knowledge of their lecturers. They even sought their lecturers' advice in utilising specific library resources, which are mostly printed textbooks or the online databases preferred by their lecturers.

iii) The postgraduates do not see a direct connection between library resources and research methodology but will seek the advice of librarians and their research supervisors. Given the in-depth nature of their research, they will try to utilise any resources that they found useful in maximising their comprehension of research methodology comprehensions and producing final research outputs and publications.

iv) In comparing the utility patterns between undergraduates and postgraduates, both groups express similar views on the library's primary roles as information provider, first of printed materials, and second of providing relevant electronic resources. Both groups of students however expressed preference for open and free resources accessible through Google search and Google Scholar, rather than accessing them through the library's Interactive Portal.

v) In contrast to means of communication and circular updates by the library via e-mails, most students found the announcements made through the library's social media platforms (Facebook and Twitter) to be more effective and have encouraged them to learn more about new resources.

\section{DISCUSSION}

Students in this study generally understood the function and role of the library as a primary source of learning activity. They applauded they initiatives undertaken by the library policymakers in providing better infrastructure and multiple resources for research methodology. However, there is a limited understanding among students, especially in viewing a critical juncture between library resources and learning research methodology. This is partly because the traditional pedagogical activity of knowledge dissemination on research methodology is mainly perceived as an exclusive jurisdiction of a lecturer, and therefore, is seen as an isolated from the role of the library as a resource provider. In light of Malaysian public universities moving towards research, we believe that this lesson should provide an instructive opportunity for the universities to realise a communication gap and enhance the effectiveness of the relationship between library resources and research methodology. Findings of the study reveal important stakeholders in library resources for research methodology and their triangular relations (a direct line and two-sided arrows) as presented in Figure 1. It illuminates the indirect role of the digital resources at the centre of these triangular relations between the following three stakeholders - the library, lecturer and student.

i) Library - Not merely a passive supporter or resource provider for research method pedagogical activities, but is equally important to the lecturer's position. The study confirms the critical role of the library in providing first-hand technical information about library resources to the students and advising the lecturer on consultation 
basis when the lecturer is planning their teaching activity. As such, the subject librarian should be invited to attend and give lectures on relevant topics during research methodology course for his/her respective academic programme. Inevitably, this will transform the students' view of both library and lecturer, and eventually affect the accessibility and utility pattern of library resources among student.

ii) Lecturer - While students recognise the traditional role of the lecturer in teaching and learning research method, they question a reality gap between the lecturer's expertise and actual resources provided by the library. Based on the authors' experience as new lecturers, it is recommended to make it mandatory for all new lecturers to attend information skills sessions provided by the library. Currently, the university provides optional information skills sessions for the university staff and postgraduate students. Apart from making information skills compulsory to all undergraduate students in the form of credited course, the library should consider to engage the Academic and Leadership Development Centre (ADeC) to integrate information skills into ACDEC's existing compulsory modules for new academics, i.e. teaching \& learning, research training, leadership and well-being and e-Learning modules. This will close the gap between the library and lecturer, especially in training new lecturers and improving their skills in teaching and research, in which all relevant stakeholders such as $\mathrm{ADeC}$, Library and the ICT Centre of the University are all integrated to achieve modular learning objective commonly associated with the student-based learning modus operandi.

iii) Student - In return, students will view their relationship with both the library and lecturer as equally important, complimentary and supporting their learning activity. FGD with the students confirmed the importance of concise and coherent communication between the university library, academic departments and student feedbacks on accessibility and utility, which are essential in ensuring the availability of relevant and necessary library resources linked to the overall quality of learning and research activity in general.

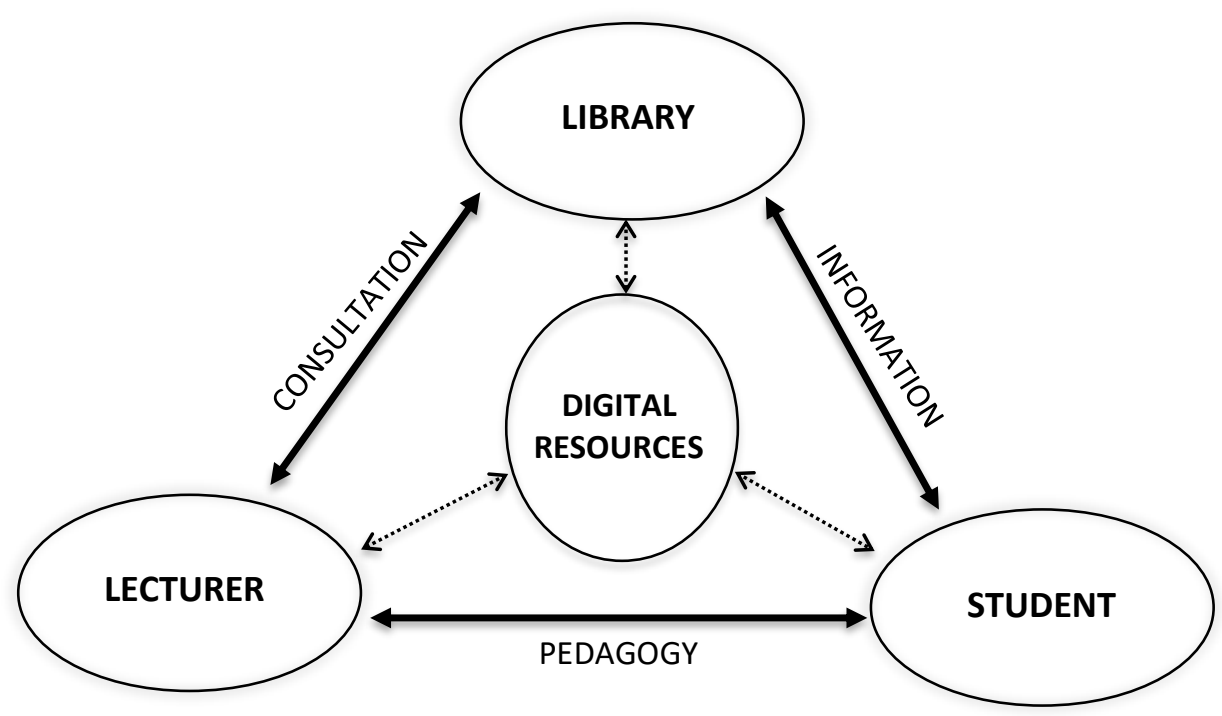

Figure 1: Positioning the Importance of Digital Resources and Relationship between the Stakeholders with Library Resources and Research Methodology 
The dotted lines and two-sided arrows in Figure 1 connect the digital resources to the stakeholders and demonstrate the position of the digital technology in supporting the effectiveness of two-ways communications among them in the process of linking library resources and research methodology.

Given the strong triangular relations and two-way communications between the stakeholders in framing the relationship between research methodology and library resources, the study demonstrates a critical role of both lecturer and library (with the supports of the digital resources) to focus more on student competency and fundamental knowledge in utilising particular resources in their research project. Student pattern of utility and accessibility are diverse, complex and determined by various factors. Our suggestions for long-term improvements will be:

i) The library should provide additional workshops on utilising specific resources. This is a clear case of SAGE Database for Research Methods or other similar technical databases that subscribed by the library. In return, the lecturers should be able to replicate their own research results (accessible through the institutional repository) by utilising the software or databases in their research methodology classes in demonstrating its utility and accessibility with their students. A similar implementation could be identified within the widespread usage of the Endnote, SPSS, NVIVO software currently provided by the library. In this respect, it is not just a matter of acquisition and collections held by the library, but also the exploitation of such resources by students. Suber (2012) posits that the usefulness of the library resources crucially depends on the competency of utilising the available resources in a learning activity.

ii) In closing the gap between research method pedagogical activities and the library resources (based on Figure 1), it is believed that there is need for the library to officially communicate with academic departments when seeking inquiries on organising workshops, seminars and short courses pertaining to technical training of resources in research method and scholarly writing at various learning stages at both the undergraduate and postgraduate level.

iii) In ensuring the reciprocity of the communication between the stakeholders (library, lecturer and student) for the purpose of continuous improvement, it is important for the relevant stakeholders to access the Course and Teaching Evaluation System (CTES) report for research methodology course that conducted by lecturers and information skill session offered by the library. This will support the existing modular learning objective of the students' learning activity.

iv) It is also important for other stakeholders to recognise the major continuous efforts undertaken by the library to improve the resource acquisition, physical infrastructure and overall information services, despite a limited annual budget provided by the university. Unfortunately, undergraduate students rarely pay serious attention to email notification from their university e-mail systems, unless it is of interests to them, or they come across such updates through the university's official social media platform (Facebook and YouTube). Meanwhile, postgraduate students admitted that they rarely take serious consideration on workshops and seminars provided by the library because they are unable to instantly recognise the relevancies of the trainings pertaining to technical aspects of library resources in their actual research project. Further study with a wider sample should be conducted, to ascertain whether such pattern could be established across the broad spectrum of arts, humanities and social sciences in the university (apart from students from the Faculty of Arts and Social Sciences). 


\section{CONCLUSION}

This study has shown that accessibility to library resources are not just a matter of making available the printed or online resources, but also the ability of relevant bodies or institutions within the university to work together to make the resources accessible. The university library should develop a more holistic model to exploit library resources in learning research methodology. In this case, the fundamental roles of the library in providing resources must be complemented by (a) the ICT Centre when ensuring a conducive and optimum Internet speeds as well as software availability, (b) comprehensive training provided by research methodology lecturers, and (c) specialised software and research tools, and competent instructors provided by academic departments; which all revolved and centred around student's competency when accessing and utilising library resources for research method towards a paradigm shift from conventional pedagogy to modular learning activity. In return, this will support the overall goal of the university in meeting its key targets for research output. It is the equal roles of both lecturer and librarian to ensure the knowledge and competency being imparted in students when engaging with library resources. Similar approaches are currently being implemented by reputable universities worldwide in the field of arts, humanities and social sciences. Conversely, the sustainability of this approach depends on the willingness, involvement and support of all stakeholders within a university.

This study closely focused on the student perspective. It suffers from several limitations, including the inability to capture the lecturer's and the library's perspective on this issue, which should be considered for future research and towards policy improvement. Nonetheless, it is important to acknowledge that the aim of this study is not to highlight problems, but opportunities to solve the problem through effective communication in the university delivery system, which will contribute to the overall improvement of utility and accessibility of the library resources for research methodology among students.

\section{ACKNOWLEDGEMENT}

This research received no specific grant from any funding agency in the public, commercial, or not-for profit sectors. All authors would like to express our sincere gratitude to the advice and comments provided by the reviewers, and consent and willingness of our students in Research Methodology classes in providing their response and opinions during the research project.

\section{REFERENCES}

Adeoye, M. O., and Popoola, S. O. 2011. Teaching effectiveness, availability, accessibility, and use of library and information resources among teaching staff of school of nursing in Osun and Oyo State, Nigeria. Library Philosophy and Practice, 525. Available at: https://digitalcommons.unl.edu/libphilprac/525/

Aguolo, C. C., and Aguolu, I. E. 2002. Librarians and information management in Nigeria. Maiduguri: Ed-Linform Services.

Allen, T. J. 1968. Organizational aspects of information flow and technology. Asia Journal of Information Management, Vol. 20, no. 11: 433-454.

Baert, P. 2005. Philosophy of the social sciences: Towards pragmatism. Cambridge: Polity Press. 
Boxall, P. C., Brady, H. E., and Collier, D. (eds.). 2008. The Oxford handbook of political methodology. Oxford: Oxford University Press.

British Library, The. 2016. The British library's 43 ${ }^{r d}$ annual account and report: 2015/16. London: The British Library.

Brown, S. and Swan, A. 2007. Researchers' use of academic libraries and their services: A report commissioned by the research information network and the consortium of research libraries. University of Southampton Institutional Repository. Available at: https://eprints.soton.ac.uk/263868/

Bryman, A. 2012. Social research methods. Oxford: Oxford University Press.

Bryman, A., Becker, S., and Sempik, J. 2008. Quality criteria for quantitative, qualitative and mixed Methods Research: A view from social policy. International Journal of Social Research Methodology, Vol. 11, no. 4: 261-276.

Cohen, A. P. 2009. Introduction to research in Chinese source materials. New Haven: Yale University Press.

Corti, L. 2012. Recent developments in archiving social research. International Journal of Social Research Methodology, Vol. 15, no. 4: 281-290.

Cox, R. 1981. Social forces, states and world Orders: Beyond international relations theory. Millennium Journal of International Relations, Vol. 10, no. 2: 126-155.

Dukic, D., and Striskovic, J. 2015. Croatian university students' use and perception of electronic resources. Library \& Information Science Research, Vol. 37, no. 3: 244-253.

Dunn, P., and Woods, L. 2016. Relationship management as a tool for engaging with the academic community. The Society of College, National and University Libraries (SCONUL). Available at: http://www.sconul.ac.uk/sites/default/files/documents/ 13_19.pdf.

Eiriemiokhale, K. A., and Ibeun, M. O. 2017. Awareness availability and accessibility of library resources by students of Kwara State University, Malate, Nigeria. Library Philosophy and Practice, 1629. Available at: https://digitalcommons.unl.edu/libphilprac/1629

Fayose, O. 2000. Library resources and their roles in education. Ibadan: University of Ibadan.

Finnemore, S. and Sikkink, K. 2001. Taking stock: The constructivist research program in international relations and comparative politics. Annual Review of Political Science, Vol. 4: 391-416.

Forrestal, V. 2015. Knowledge management for libraries. London: The Rowman and Littlefield.

Gerring, J. 2012. Social science methodology: A unified framework. Cambridge: Cambridge University Press.

Griffiths, J. R. and Brophy, P. 2005. Student searching behaviour and the web: Use of academic resources and google. Library Trends, Vol. 53, no. 4: 539-554.

Hislop, D. 2013. Knowledge management in organizations: A critical introduction. Oxford: Oxford University Press.

Jupp, V. (ed.) 2006. The SAGE dictionary of social research methods. London: Sage Publications.

King, G., Keohane, R. O., and Verba, S. 1996. Designing social inquiry: Scientific inference in qualitative research. Princeton: Princeton University Press.

Klotz, A., and Prakash, D. (ed.) 2008. Qualitative methods in international relations: A pluralist guide. New York: Palgrave Macmillan.

Krejcie, R. V. and Morgan, D. W. 1970. Determining sample size for research activities. Educational and Psychological Measurement, Vol. 30: 607-610.

Lamont, C. 2013. Research methods in international relations. London: SAGE Publication.

Leavy, P. (ed.) 2014. The Oxford handbook of qualitative research. Oxford: Oxford University Press. 
Maitaothong, T., Tuamsuk, K., and Techamanee, Y. 2012. The roles of university libraries in supporting the integration of information literacy in the course instruction. Malaysian Journal of Library \& Information Science, Vol. 17, no. 1: 51-64.

Marshall, S. 2016. Creating pre-arrival library support for international students. The Society of College, National and University Libraries (SCONUL). Available at: http://www.sconul.ac.uk/sites/default/files/documents/20_15.pdf

Maximilliano, M., Clasing, P., Kelly, N., Gonzalez, C., Jara, M., Alarcon, R., Sandoval, A., and Saurina, E. 2016. Library resources and students' learning outcomes: Do all the resources have the same impact on learning? The Journal of Academic Librarianship, Vol. 42, no. 5 : 551-556.

Nagata, H., Toda, A., and Kytömäki, P. 2007. Students' patterns of library use and their learning outcomes. Graduate School of Library and Information Science, University of Tsukuba, Japan. Available at: http://www.kc.tsukuba.ac.jp/div-comm/pdf/report0704.pdf.

Newman, W. L. 2013. Social research methods: Qualitative and quantitative approaches. New York: Pearson Education.

O'Connor, S. (ed.) 2015. The facet library management collection in disruptive times: Skills and knowledge for an uncertain future. London: The Facet Publishing.

Oyewusi, F. O., and Oyeboade, S. A., 2009. An empirical study of accessibility and use of library resources by undergraduates in a Nigerian State University of Technology. Library Philosophy and Practice, 277. Available at: https://digitalcommons.unl.edu/ libphilprac/277/.

Popoola, S. O., and Haliso, Y. 2009. Use of library information resources and services as predator of teaching effectiveness of social scientist in Nigerian universities. African Journal of Library, Archive and Information Science, Vol. 19, no. 1: 65-77.

Sandra, H. and Heath, O. 2012. Researching politics: Methods and practical skills. Oxford: Oxford University Press.

Rosenberg, V. 1967. Factors affecting the preferences of industrial personnel for information gathering methods. Information Storage and Retrieval Journal, Vol. 3: 199-129.

Suber, P. 2012. Open access. Cambridge, M. A.: The MIT Press.

Tickner, J. A. 2005. What is your research program? Some feminist answers to international relations methodological questions. International Studies Quarterly, Vol. 49, no. 1: 1-22.

Ugah, A. D. 2008. Availability and accessibility of information sources and the use of library services at Michael Okpara University of Agriculture. Library Philosophy and Practice, 190. Available at: http://digitalcommons.unl.edu/libphilprac/190/.

Walton, J. 1992. 'Making the theoretical case', in Ragin, C., and Becker, C. (eds.). What is a case study: Exploring the foundations of social inquiry. Cambridge: Cambridge University Press, 122-156.

Werhane, P. H., and Moriarty, B. 2009. Moral imagination and management decision making. Business roundtable institute for corporate ethics. Available at: Business Roundtable Institute for Corporate Ethics, Available at: http://www.corporate- ethics.org/pdf /moral _imagination.pdf.

Yang, S. 2013. Surviving as a qualitative researcher in a quantitative world: a personal reflection. International Journal of Social Research Methodology, Vol. 16, no. 1: 81-85.

Yin, R. 1984. Case study research: Design and methods. Thousand Oaks: SAGE publications.

$\mathrm{Zha}, \mathrm{X}$., Li, J., and Yan, Y. 2012. Understanding usage transfer from print resources to electronic resources: A survey of users of Chinese university libraries. Serials Review, Vol. 38, no. 2: 93-98. 